\title{
Living arrangements of older adults in Lebanon: correlates of living with married children
}

\author{
O. Shideed, ${ }^{1}$ A. Sibai ${ }^{7}$ and R. Tohme
}

$$
\text { ترتيبات المعيشة للكبار من البالغين في لبنان: ارتباطات معيشتهم بأولادهم المتزوجين محين }
$$

الخلاصة: يمثل الازدياد السريع في نسبة الكبار من البالغين إلى مجمل السكان تحديات ضخمة تواجه أصحاب القرار السياسي. وقد أجرت البرت الباحثات

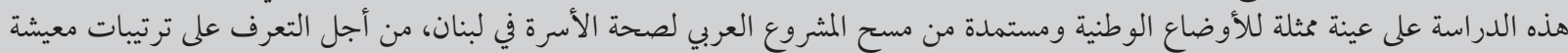

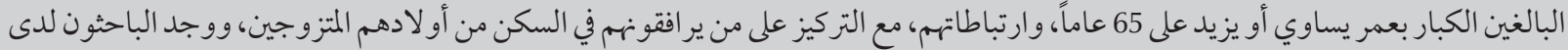

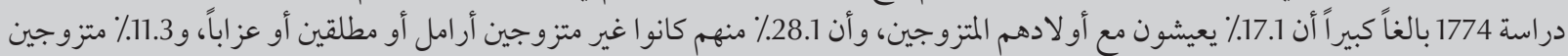

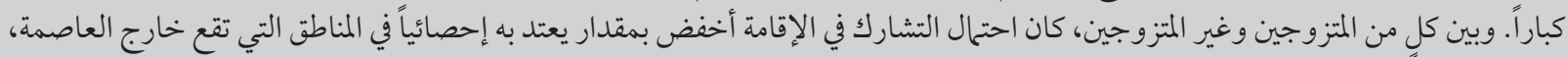

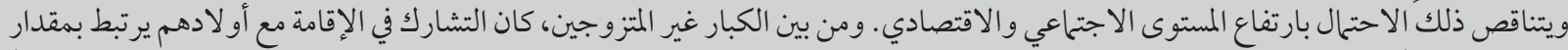

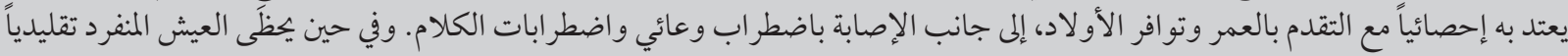

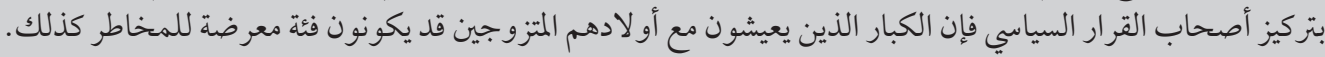

ABSTRACT Rapid increases in the proportion of older adults in the population present major challenges to policy-makers worldwide. Using a nationally representative sample from the PAPFAM survey in Lebanon, this study examined the living arrangements of older adults (aged $\geq 65$ years), and their correlates, with a focus on co-residence with married children. Of 1774 older adults $17.1 \%$ co-resided with their married children: $28.1 \%$ of the 559 unmarried (widowed/divorced/single) and 11.3\% of the 1071 married older adults. Among both the married and unmarried, the likelihood of co-residence was significantly lower in regions outside the capital and decreased with increasing socioeconomic status. Among the unmarried elderly, co-residence with a married child was also significantly associated with increasing age and availability of sons, as well as presence of a vascular disorder and speech problems. While solitary living has traditionally been the focus for policy-makers, older people living with a married child may also be a vulnerable group.

Modalités de vie des personnes âgées au Liban : corrélats de la cohabitation avec des enfants mariés

RÉSUMÉ L'augmentation rapide de la proportion de personnes âgées dans la population pose des difficultés majeures aux responsables de l'élaboration des politiques dans le monde. À l'aide d'un échantillon représentatif au niveau national issu de l'enquête du Projet panarabe pour la santé de la famille (PAPFAM) au Liban, la présente étude a examiné les modalités de vie des personnes agées (65 ans ou plus) et leurs corrélats, en étudiant plus particulièrement la cohabitation avec des enfants mariés. Sur 1774 personnes âgées, 17,1 \% cohabitaient avec leurs enfants mariés, tout comme 28,1\% des 559 personnes âgées sans conjoint (veufs/divorcés/célibataires) et 11,3\% des 1071 personnes âgées mariées. Chez les personnes âgées mariées comme chez les autres, la probabilité de cohabiter était très inférieure dans les régions par rapport à la capitale. En outre, plus le statut socioéconomique augmentait, plus cette probabilité diminuait. Parmi les personnes âgées sans conjoint, la cohabitation avec un enfant marié était fortement associée à un âge plus avancé et au fait d'avoir des fils, ainsi qu'à la présence de troubles vasculaires et de la parole. Si les personnes âgées vivant seules ont traditionnellement fait l'objet d'attention de la part des responsables politiques, celles partageant un toit avec un enfant marié peuvent aussi représenter un groupe vulnérable.

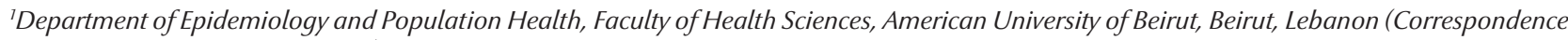
to O. Shideed: shideedo@who.int).

Received: 28/06/12; accepted: 20/02/13 


\section{Introduction}

Recent studies in Lebanon have projected an increase in the proportion of older adults in the population, similar to contemporary Europe [1]. Yet, amid a number of other urgent problems, ageing and issues related to the health and care of older adults have not been adequately addressed by policy-makers as an area of priority concern. In most Middle Eastern countries, societies value family ties, and older adults are viewed as a resource to the family. While cultural and ethical values still protect the majority of older people in Lebanon, it is likely that recent changes in family structure, with a trend towards smaller families, youth migration and increasing participation of women in the workforce have weakened the family as a social institution $[1,2]$.

Studies have underscored the importance of living arrangements to the well-being of older adults $[3,4]$. This issue is of great importance especially in regions characterized by the scarcity of social security safety nets, public institutions and pension plans. As mentioned earlier, Lebanon is undergoing a demographic transformation characterized by lower mortality and fertility rates and longer longevity. But rather than occurring in isolation, the transformation is embedded in cultural, social and economic circumstances that are also changing and thereby leading to an imbalance in the traditional relationships and exchange of resources between generations [5]. The traditional concept of intergenerational support and provision of care and assistance to older adults is "on the brink" [6].

One living arrangement of particular interest in the Lebanese context is living with married children. In Lebanon as in other Arab countries, the norm is for adult children to co-reside with their parents until marriage, when they establish individual households $[7,8]$. The literature has indicated that living with children provides mutual benefit for the older adult who receives social, financial and health assistance from the adult child and in turn helps in caring for the grandchildren or caring for the house [9-13]. Married children are often considered as important resources of economic security for their older parents [14]. Older women are more likely to live with their children in Egypt, because women outlive men, and are more disabled at older ages [8]. A higher percentage of older adults co-reside with their married male child than with their married female child $[8,9]$.

Published studies on the living arrangements of older adults in the Eastern Mediterranean Region as well as in Lebanon remain limited in scope, and a majority lacked health-related characteristics that are regarded in the literature as significant confounders in the older person's choice of living arrangement [9]. Using data from a national study conducted in Lebanon, the current study aimed to examine the living arrangements of older adults in Lebanon, and their correlates, with a focus on those living with children. Earlier studies have shown that coresidence with children is likely to bring material advantages, especially for the older adults. Nevertheless, it is unclear whether living with married children presents comparable advantages as living with unmarried children [15]. The distinction is particularly important because in the context of Lebanon, children are expected to live with parents until marriage.

\section{Methods}

\section{Study design}

This study of older Lebanese compared the living arrangements of married and currently unmarried (widowed, divorced or separated) individuals. We also assessed the demographic, socioeconomic and health correlates of living with married children compared to other living arrangements.

\section{Study population and sample}

The study population consisted of persons aged $\geq 65$ years who were included in the Household Health Survey conducted in 2004 by the Lebanese Ministry of Social Affairs in collaboration with the League of Arab States as part of the Pan Arab Project for Family Health (PAPFAM) [16]. The sample for the study was selected using a 3-stage stratified cluster sample design. In the first stage, 15 geographical areas were randomly selected from the 6 governorates of Lebanon, and in the second, 449 population survey units were randomly sampled. The third stage included the sampling of 7098 main dwellings. A total of 6505 households were visited and interviews were completed for 5532, yielding a response rate of $85 \%$. A total of 1812 older adults were identified, of whom 1774 completed the interviews, yielding a $97.9 \%$ response rate.

The study sample included evermarried subjects with at least 1 child alive. Older adults who were never married or did not have any children still alive were excluded because they were not at-risk for the outcome (living with married children). The sample included 1684 (95.7\%) ever-married individuals and $52(3.0 \%)$ with no children alive. The final analysis was based on data from 1630 older adults, 1071 married and 559 unmarried.

\section{Variables}

The outcome variable of interest was the living arrangements of older adults. In this study living arrangements were initially grouped into 5 mutually exclusive categories according to the relation of the older adult to other household members: living alone, living with spouse (no children), living with unmarried children (with or without spouse), living with at least 1 married child and/or offspring (with or without spouse) and living with non-spouse/ non-children others. Except for those living alone, the remaining categories included those who may or may not have 
been living with a sibling, other relatives or non-relative others. For the objective of the study, living arrangements were dichotomized into a binary variable: living with married children versus all other arrangements.

Exposure variables which assessed the demographic, socioeconomic and health status of the sample were included. These variables, according to existing literature, were expected to have an effect on the living arrangements of older adults.

Demographic variables included age $(65-69,70-74,75-79,80-84$ or $\geq$ 85 years), sex male or female, region Beirut, Mount Lebanon, North Lebanon, South Lebanon, Nabatieh or Beka'a, number of sons and daughters alive $(0,1-2,3-4$ or $\geq 5)$ and marital status (single, married, widowed, divorced or separated). Because few respondents reported being single, divorced or separated, they were merged for analysis with those who were widowed into one category: unmarried.

Socioeconomic variables included educational level (no formal schooling, attended preparatory school or higher education), work status (never worked, worked in past or currently working), financial status in household (financially independent, having dependants or financially dependent on others), income sufficient for main expenses (used to assess adequacy of monthly income, dichotomized yes/no), monthly per capita income.

Health-related variables included self-rated health assessed by asking the older adult "Do you think your health in general is good, fair or bad?" (coded in 3 categories). Participants were asked if they suffered from any disabling chronic diseases that required continuous monitoring: hypertension, vascular disorder, diabetes mellitus or pulmonary disorder (coded yes/no). They were asked if they had any communication problems for 3 senses: speech, hearing and sight (coded yes/no). Difficulty with activities of daily living (ADL) [17] were assessed for 5 activities: using toilet, bathing, dressing, moving in/out of chair and eating (coded no help or partial/total help), as well as the total ADL score.

\section{Statistical analysis}

Frequency distributions of living arrangements as well as baseline characteristics (demographic, socioeconomic and health-related conditions ) were evaluated for the total sample and for married and unmarried individuals separately. Differences by marital status were assessed using Pearson chi-squared test of association. Ageadjusted odds ratios (OR) and their respective 95\% confidence intervals (CI) comparing each exposure with its reference category were estimated.

A multivariate logistic regression model was estimated for married and unmarried individuals separately. Variables included in the multivariate model were age, sex, region, number of sons alive and number of daughters alive, literacy, monthly per capita income, chronic diseases, ADL score and communication problems. OR and 95\% CI were obtained, and significance was assessed via the Wald test statistic.

\section{Results}

\section{Overview of the study population}

The total sample included 1630 older adults: 1071 (65.7\%) married and 559 (34.2\%) unmarried. Overall, $41.3 \%$ of the individuals had 1-2 sons alive and $43.2 \%$ had $1-2$ daughters alive. As for the socioeconomic factors, they were similar for the 2 groups. With regard to literacy, $59.0 \%$ of the older adults had no formal schooling and almost $40 \%$ reported a monthly per capita income $<$ US\$ 100. Table 1 shows the distribution of demographic and socioeconomic characteristics among the study population, stratified by marital status.
Compared with married individuals, those who were unmarried were significantly more likely to be aged $\geq 85$ years (9.5\% versus $2.8 \% ; P<0.001$ ), to be female $(78.9 \%$ versus $32.5 \% ; P<0.001)$ and to be living in Beirut (19.1\% versus $10.9 \% ; P<0.001$ ).

The distribution of health-related conditions among married and unmarried individuals is presented in Table 2. Currently unmarried older adults were slightly more likely to suffer from illnesses and co-morbidities than married older adults. Currently unmarried older adults had significantly higher ADL scores, indicating need greater need for help. Difficulties in hearing and sight was significantly more common for currently unmarried than married respondents: (19.1\% versus $11.9 \% P$ $<0.001)$ and $(22.9 \%$ versus $13.9 \% P<$ $0.001)$ respectively.

\section{Living arrangements}

The findings revealed that the highest percentage of older adults (47.3\%) lived in a nuclear family with their unmarried children, with or without their spouse (Table 3). Living with at least 1 married child accounted for $17.1 \%$ of the total sample, with the currently unmarried being more than twice as likely to be living with their married children as their married counterparts (28.1\% versus $11.3 \%$ ). Around $10 \%$ were living alone and an additional $24.2 \%$ were living with their spouse. The majority of the older adults (91.0\%) reported being satisfied with their current living arrangement and there was no difference between married and unmarried individuals.

\section{Associations between co- variables and living with married children}

Binary logistic regression was carried out to assess associations with our main outcome variable, living with married children compared with other living arrangements. Tables 4 and 5 present the age-adjusted OR for demographic, 


\begin{tabular}{|c|c|c|c|c|c|c|c|}
\hline \multirow[t]{2}{*}{ Sociodemographic variables } & \multicolumn{2}{|c|}{$\begin{array}{c}\text { Total } \\
(n=1630)\end{array}$} & \multicolumn{2}{|c|}{$\begin{array}{l}\text { Married } \\
(n=1071)\end{array}$} & \multicolumn{2}{|c|}{$\begin{array}{c}\text { Unmarried }^{\mathrm{a}} \\
(n=559)\end{array}$} & \multirow[t]{2}{*}{$P$-value } \\
\hline & No. & $\%$ & No. & $\%$ & No. & $\%$ & \\
\hline \multicolumn{8}{|l|}{ Age (years) } \\
\hline $65-69$ & 504 & 30.9 & 375 & 35.0 & 129 & 23.1 & $<0.001$ \\
\hline $70-74$ & 540 & 33.1 & 378 & 35.3 & 162 & 29.0 & \\
\hline $75-79$ & 326 & 20.0 & 198 & 18.5 & 128 & 22.9 & \\
\hline $80-84$ & 178 & 10.9 & 91 & 8.5 & 87 & 15.6 & \\
\hline$\geq 85$ & 83 & 5.1 & 30 & 2.8 & 53 & 9.5 & \\
\hline Mean (SD) & \multicolumn{2}{|c|}{$73.2(6.1)$} & \multicolumn{2}{|c|}{$72.3(5.5)$} & \multicolumn{2}{|c|}{$74.9(6.8)$} & $<0.001$ \\
\hline \multicolumn{8}{|l|}{ Sex } \\
\hline Male & 841 & 51.6 & 723 & 67.5 & 118 & 21.1 & $<0.001$ \\
\hline Female & 788 & 48.4 & 348 & 32.5 & 440 & 78.9 & \\
\hline \multicolumn{8}{|l|}{ Region } \\
\hline Beirut & 224 & 13.7 & 117 & 10.9 & 107 & 19.1 & $<0.001$ \\
\hline Beka'a & 177 & 10.9 & 126 & 11.8 & 51 & 9.1 & \\
\hline Mount Lebanon & 632 & 38.7 & 394 & 36.8 & 238 & 42.5 & \\
\hline Nabatieh & 125 & 7.7 & 92 & 8.6 & 33 & 5.9 & \\
\hline North & 310 & 19.0 & 220 & 20.5 & 90 & 16.1 & \\
\hline South & 163 & 10.0 & 122 & 11.4 & 41 & 7.3 & \\
\hline \multicolumn{8}{|l|}{ No. of sons alive } \\
\hline 0 & 111 & 6.8 & 86 & 6.3 & 43 & 7.7 & 0.006 \\
\hline $1-2$ & 673 & 41.3 & 422 & 39.4 & 251 & 44.9 & \\
\hline $3-4$ & 578 & 35.5 & 382 & 35.7 & 196 & 35.1 & \\
\hline$\geq 5$ & 268 & 16.4 & 199 & 18.6 & 69 & 12.3 & \\
\hline \multicolumn{8}{|l|}{ No. of daughters alive } \\
\hline 0 & 107 & 6.6 & 68 & 6.4 & 39 & 7.0 & 0.510 \\
\hline $1-2$ & 703 & 43.2 & 451 & 42.1 & 252 & 45.1 & \\
\hline $3-4$ & 540 & 33.1 & 359 & 33.6 & 181 & 32.4 & \\
\hline$\geq 5$ & 279 & 17.1 & 192 & 17.9 & 87 & 15.6 & \\
\hline \multicolumn{8}{|l|}{ Literacy } \\
\hline No formal schooling & 948 & 59.0 & 588 & 55.6 & 360 & 65.3 & $<0.001$ \\
\hline$\leq$ Preparatory & 525 & 32.6 & 360 & 34.1 & 165 & 29.9 & \\
\hline Higher & 135 & 8.4 & 109 & 10.3 & 26 & 4.7 & \\
\hline \multicolumn{8}{|l|}{ Per capita income (US\$/month) } \\
\hline$\leq 50$ & 270 & 16.6 & 199 & 18.6 & 71 & 12.7 & $<0.001$ \\
\hline $50-\leq 100$ & 375 & 23.0 & 247 & 23.1 & 128 & 22.9 & \\
\hline $100-\leq 150$ & 273 & 16.7 & 167 & 15.6 & 106 & 19.0 & \\
\hline $150-\leq 200$ & 177 & 10.9 & 138 & 12.9 & 39 & 7.0 & \\
\hline$\geq 200$ & 375 & 23.0 & 224 & 20.9 & 151 & 27.0 & \\
\hline No response & 160 & 9.8 & 96 & 9 & 64 & 11.4 & \\
\hline
\end{tabular}

${ }^{a}$ Single, divorced, separated and widowed. $S D=$ standard deviation.

socioeconomic and health-related older adults in Beirut were more likely adults with at least 1 son were signififactors. The likelihood of living with to co-reside with their married children cantly more likely to be co-residing with married children increased signifi- compared with those in all other gov- a married child (OR = 4.08; 95\% CI: cantly with increasing age. In general, ernorates. Currently unmarried older 1.77-9.41), and married individuals 


\begin{tabular}{|c|c|c|c|c|c|c|c|}
\hline \multirow[t]{2}{*}{ Health-related variables } & \multicolumn{2}{|c|}{$\begin{array}{c}\text { Total } \\
(n=1630)\end{array}$} & \multicolumn{2}{|c|}{$\begin{array}{l}\text { Married } \\
(n=1071)\end{array}$} & \multicolumn{2}{|c|}{$\begin{array}{c}\text { Unmarried }^{\mathrm{a}} \\
(n=559)\end{array}$} & \multirow[t]{2}{*}{$P$-value } \\
\hline & No. & $\%$ & No. & $\%$ & No. & $\%$ & \\
\hline \multicolumn{8}{|c|}{ Chronic diseases } \\
\hline \multicolumn{8}{|l|}{ Hypertension } \\
\hline Yes & 596 & 36.6 & 345 & 32.2 & 251 & 44.9 & $<0.001$ \\
\hline No & 1034 & 63.4 & 726 & 67.8 & 308 & 55.1 & \\
\hline \multicolumn{8}{|l|}{ Vascular disorder } \\
\hline Yes & 434 & 26.6 & 262 & 24.5 & 172 & 30.8 & 0.006 \\
\hline No & 1196 & 73.4 & 809 & 75.5 & 387 & 69.2 & \\
\hline \multicolumn{8}{|l|}{ Diabetes mellitus } \\
\hline Yes & 358 & 21.9 & 218 & 20.3 & 140 & 25.0 & 0.029 \\
\hline No & 1273 & 78.1 & 854 & 79.7 & 419 & 75.0 & \\
\hline \multicolumn{8}{|l|}{ Pulmonary disorder } \\
\hline Yes & 101 & 6.2 & 61 & 5.7 & 40 & 7.2 & 0.244 \\
\hline No & 1530 & 93.8 & 1011 & 94.3 & 519 & 92.8 & \\
\hline \multicolumn{8}{|c|}{ Activities of daily living } \\
\hline \multicolumn{8}{|l|}{ ADL score } \\
\hline 0 & 1387 & 85.0 & 946 & 88.2 & 441 & 78.8 & $<0.001$ \\
\hline 1 & 52 & 3.2 & 26 & 2.4 & 26 & 4.6 & \\
\hline 2 & 46 & 2.8 & 19 & 1.8 & 27 & 4.8 & \\
\hline 3 & 34 & 2.1 & 15 & 1.4 & 19 & 3.4 & \\
\hline 4 & 30 & 1.8 & 13 & 1.2 & 17 & 3.0 & \\
\hline 5 & 83 & 5.1 & 53 & 4.9 & 30 & 5.4 & \\
\hline Mean (SD) & \multicolumn{2}{|c|}{$0.48(1.29)$} & \multicolumn{2}{|c|}{$0.40(1.22)$} & \multicolumn{2}{|c|}{$0.63(1.40)$} & $<0.001$ \\
\hline \multicolumn{8}{|c|}{ Communication problems } \\
\hline \multicolumn{8}{|l|}{ Speech problems } \\
\hline Yes & 98 & 6.0 & 56 & 5.2 & 42 & 7.5 & 0.065 \\
\hline No & 1532 & 94.0 & 1015 & 94.8 & 517 & 92.5 & \\
\hline \multicolumn{8}{|l|}{ Hearing problems } \\
\hline Yes & 234 & 14.4 & 127 & 11.9 & 107 & 19.1 & $<0.001$ \\
\hline No & 1396 & 85.6 & 944 & 88.1 & 452 & 80.9 & \\
\hline \multicolumn{8}{|l|}{ Sight problems } \\
\hline Yes & 277 & 17.0 & 149 & 13.9 & 128 & 22.9 & $<0.001$ \\
\hline No & 1353 & 83.0 & 922 & 86.1 & 431 & 77.1 & \\
\hline
\end{tabular}

${ }^{a}$ Single, divorced, separated and widowed.

$S D=$ standard deviation .

with at least 1 daughter were more likely to live with a married child, although this was not significant $(\mathrm{OR}=2.23 ; 95 \%$ CI: $0.92-5.37)$. With regard to socioeconomic factors, the overall the results showed that married and unmarried individuals of higher socioeconomic status were less likely to be living with married children. This was evident for monthly percapita; as income increased, the likelihood of living with married children significantly decreased.

The data also showed that both married and unmarried older adults living with married children were more likely to report chronic diseases. For unmarried older adults, hypertension and vascular disease were significantly associated with living with married children $(\mathrm{OR}=1.67$; 95\% CI: $1.15-2.43$ and $\mathrm{OR}=2.02 ; 95 \% \mathrm{CI}: 1.37-2.98$ respectively). Difficulty in performing ADL was also significantly associated with living with married children among unmarried individuals ( $\mathrm{OR}=1.16 ; 95 \%$ CI: 1.02-1.32). Similarly, older adults living with married children were significantly more likely to report communication problems; specifically, there were higher odds of having hearing and 


\begin{tabular}{|c|c|c|c|c|c|c|c|}
\hline \multirow[t]{2}{*}{ Living arrangements } & \multicolumn{2}{|c|}{$\begin{array}{c}\text { Total } \\
(n=1630)\end{array}$} & \multicolumn{2}{|c|}{$\begin{array}{l}\text { Married } \\
(n=1071)\end{array}$} & \multicolumn{2}{|c|}{$\begin{array}{l}\text { Unmarried }^{\mathrm{a}} \\
\qquad(n=559)\end{array}$} & \multirow[t]{2}{*}{$P$-value } \\
\hline & No. & $\%$ & No. & $\%$ & No. & $\%$ & \\
\hline Alone & 171 & 10.5 & 0 & 0.0 & 171 & 30.6 & $<0.001$ \\
\hline Spouse & 395 & 24.2 & 395 & 36.9 & 0 & 0.0 & \\
\hline Unmarried children & 771 & 47.3 & 555 & 51.8 & 216 & 38.6 & \\
\hline Married children & 278 & 17.1 & 121 & 11.3 & 157 & 28.1 & \\
\hline $\begin{array}{l}\text { Non-spouse/non-children } \\
\text { others }\end{array}$ & 15 & 0.9 & 0 & 0.0 & 15 & 2.7 & \\
\hline
\end{tabular}

${ }^{a}$ Single, divorced, separated and widowed.

sight problems among married (OR $=1.99 ; 95 \%$ CI: $1.21-3.27$ and $\mathrm{OR}=$ 1.80; 95\% CI: $1.12-2.89$ respectively ) than currently unmarried individuals $(\mathrm{OR}=1.69 ; 95 \% \mathrm{CI}: 1.09-2.64$ and $\mathrm{OR}$ $=1.41 ; 95 \%$ CI: $0.92-2.16$ respectively). Among currently unmarried individuals living with married children, difficulty in speech was 3.5 times more common than among the married (95\% CI: 1.85-6.72).

\section{Multivariate analysis}

Tables 4 and 5 also show the multivariate analyses for the selected variables. Age was found to be a significant factor for living with married children only in unmarried individuals ( $\mathrm{OR}=1.79 ; 95 \%$ CI: 1.08-2.93), whereas region was a significant predictor for living with married children among both married and unmarried individuals $(\mathrm{OR}=0.36 ; 95 \%$ CI: $0.20-0.63$ and $\mathrm{OR}=0.40 ; 95 \% \mathrm{CI}$ : $0.24-0.67$ respectively), with a negative association in other regions compared with Beirut. Among the currently unmarried, having at least 1 son alive significantly increased the likelihood of living with a married child $(\mathrm{OR}=5.40$; 95\% CI: 2.12-13.74). A significant association was observed with monthly percapita; as monthly income increased, older adults were less likely to live with their married children (Table 4).

For chronic diseases, only vascular disease among the currently unmarried retained its significant association with living with a married child (OR $=1.69 ; 95 \% \mathrm{CI}: 1.08-2.64)$. For communication problems, only speech among the currently unmarried was significantly associated with co-residing with a married child (OR $=4.19$; $95 \%$ CI: 1.71-10.23) (Table 5).

\section{Discussion}

Living with others, in particular children, has been considered as one arrangement in which older persons are closer to their social networks and are more likely to receive support when needed. It is expected that co-residence would be associated with mutual benefit for both the older adult and their children by increasing material and non-material resource exchanges between the generations, as well as expanding their support networks [18]. However, it is not clear whether the advantages conferred by living with married children are comparable to those of living with unmarried children [15].

The main purpose of this study was to assess the living arrangements of older adults and the correlates of living with married children among older adults in Lebanon. In the Lebanese context, the norm is for children to live with their parents until they are married, at which time they are then expected to leave their parent's home and establish their own households. The results of this study show that overall $17.1 \%$ of older adults in Lebanon live with at least 1 married child. This percentage is similar to that of a previous study conducted in Beirut
(1993-1994), where the percentage of older adults living with at least 1 married child was $19.1 \%$ [14]. The likelihood of living with married children was around 2.5 times greater among the unmarried when compared with the married older adults (28.1\% versus $11.3 \%$.)

Consistent with other studies, this study demonstrated that older adults co-residing with married children was positively associated with the availability of living children and with age of the older adult $[2,6,9,14,17]$. In the Lebanese context, due to strong family relations, increases in age and in dependency (both financial and physical), is often accommodated by the family.

Living with married children was inversely associated with socioeconomic status, including education of the older person and monthly per capita income. Also, those co-residing with married children were more likely to be receiving aid from government sources than their unmarried counterparts. These results were consistent for both married and unmarried people, although the strength of the association was stronger among the married. Findings from other published studies are inconsistent in this regard. For example, studies elsewhere in the Arab region showed co-residence with children was associated with higher socioeconomic status. Studies conducted in Kuwait by Shah et al. [19] and in Egypt by Yount [8] found that high income and standards of living encouraged co-residence due to the 


\begin{tabular}{|c|c|c|c|c|c|c|c|c|}
\hline \multirow{3}{*}{$\begin{array}{l}\text { Sociodemographic } \\
\text { variable }\end{array}$} & \multicolumn{4}{|c|}{ Married } & \multicolumn{4}{|c|}{ Unmarried $^{\mathrm{a}}$} \\
\hline & \multicolumn{2}{|c|}{ Age-adjusted } & \multicolumn{2}{|c|}{ Multivariate adjusted } & \multicolumn{2}{|c|}{ Age-adjusted } & \multicolumn{2}{|c|}{ Multivariate adjusted } \\
\hline & OR & $95 \% \mathrm{Cl}$ & OR & $95 \% \mathrm{Cl}$ & OR & $95 \% \mathrm{Cl}$ & OR & $95 \% \mathrm{Cl}$ \\
\hline \multicolumn{9}{|l|}{ Age (years) } \\
\hline $65-79$ & \multicolumn{2}{|c|}{ Ref. } & & & \multicolumn{2}{|c|}{ Ref. } & & \\
\hline$\geq 80$ & $1.77^{\mathrm{b}}$ & $1.06-2.95$ & 1.36 & $0.76-2.45$ & $1.71^{\mathrm{b}}$ & $1.15-2.56$ & $1.79^{\mathrm{b}}$ & $1.08-2.93$ \\
\hline \multicolumn{9}{|l|}{ Sex } \\
\hline Male & \multicolumn{2}{|c|}{ Ref. } & & & \multicolumn{2}{|c|}{ Ref. } & & \\
\hline Female & 1.05 & $0.70-1.57$ & 0.99 & $0.64-1.53$ & 1.20 & 0.751 .89 & 0.98 & $0.58-1.66$ \\
\hline \multicolumn{9}{|l|}{ Region } \\
\hline Beirut & \multicolumn{2}{|c|}{ Ref. } & & & \multicolumn{2}{|c|}{ Ref. } & & \\
\hline Other & $0.50^{\mathrm{b}}$ & $0.30-0.82$ & $0.36^{\mathrm{b}}$ & $0.20-0.63$ & $0.44^{\mathrm{b}}$ & $0.28-0.68$ & $0.40^{\mathrm{b}}$ & $0.24-0.67$ \\
\hline \multicolumn{9}{|l|}{ No. of sons alive } \\
\hline 0 & \multicolumn{2}{|c|}{ Ref. } & & & \multicolumn{2}{|c|}{ Ref. } & & \\
\hline$\geq 1$ & 1.23 & $0.60-2.53$ & 0.96 & $0.44-2.10$ & $4.08^{b}$ & $1.77-9.41$ & $5.40^{\mathrm{b}}$ & $2.12-13.7$ \\
\hline \multicolumn{9}{|l|}{$\begin{array}{l}\text { No. of daughters } \\
\text { alive }\end{array}$} \\
\hline 0 & \multicolumn{2}{|c|}{ Ref. } & & & \multicolumn{2}{|c|}{ Ref. } & & \\
\hline$\geq 1$ & 2.23 & $0.92-5.37$ & 2.07 & $0.82-5.26$ & 1.80 & $0.93-3.48$ & 0.85 & $0.40-1.83$ \\
\hline \multicolumn{9}{|l|}{ Literacy } \\
\hline $\begin{array}{l}\text { No formal } \\
\text { schooling }\end{array}$ & \multicolumn{2}{|c|}{ Ref. } & \multicolumn{6}{|c|}{ Ref. } \\
\hline Other & 0.76 & $0.51-1.13$ & 0.91 & $0.59-1.42$ & 0.76 & $0.51-1.13$ & 1.16 & $0.72-1.87$ \\
\hline \multicolumn{9}{|l|}{$\begin{array}{l}\text { Per capita income } \\
\text { (US\$/month) }\end{array}$} \\
\hline$\leq 50$ & \multicolumn{2}{|c|}{ Ref. } & \multicolumn{6}{|c|}{ Ref. } \\
\hline $50-\leq 150$ & $0.52^{\mathrm{b}}$ & $0.32-0.82$ & $0.52^{\mathrm{b}}$ & $0.32-0.86$ & $0.39^{\mathrm{b}}$ & $0.23-0.67$ & $0.38^{\mathrm{b}}$ & $0.21-0.69$ \\
\hline$\geq 150$ & $0.29^{b}$ & $0.17-0.50$ & $0.26^{\mathrm{b}}$ & $0.14-0.48$ & $0.14^{\mathrm{b}}$ & $0.08-0.27$ & $0.12^{\mathrm{b}}$ & $0.06-0.25$ \\
\hline \multicolumn{9}{|l|}{ Government aid } \\
\hline No & \multicolumn{2}{|c|}{ Ref. } & & & \multicolumn{2}{|c|}{ Ref. } & & \\
\hline Yes & 2.02 & $0.78-5.23$ & 2.19 & $0.81-5.90$ & 1.94 & $0.77-4.93$ & 2.31 & $0.80-6.65$ \\
\hline
\end{tabular}

${ }^{a}$ Single, divorced, separated and widowed; ${ }^{b} P<0.05$.

Ref. $=$ reference category.

$O R=$ odds ratio; $C I=$ confidence interval.

financial ability of the older adult to keep his/her children close. In contrast, studies conducted in the United States [20] and in selected countries in the Far East [21] have shown an inverse relationship between co-residence and socioeconomic status. The association between lower socioeconomic status and co-residence implies that pooling of resources, in an aim to overcome scarcity of financial resources, is the driving factor for such an arrangement. In other words, higher per capita income enables purchase of privacy. This explanation is supported by our finding that co-residence was more likely to occur in Beirut compared with other governorates. The high costs of living associated with residing in the capital [22] may explain these results. Our findings concur with those found in Turkey, where living in metropolitan areas was associated with co-residence due to high costs of housing and living $[23,24]$. The dynamics of living with married children (i.e. who moved in with whom, and why?) could not be determined in the current study.
With regard to health-related factors, this study showed that selected co-morbid conditions, such as vascular disorders, hypertension and communication problems, were associated with living with a married child, and the findings were only significant among the unmarried. An earlier study conducted in Beirut showed that co-residence with a married child was the most disadvantageous among all living arrangements with the highest all-cause and cardiovascular disease mortality risk [14]. However, difficulty in performing ADL in this study 


\begin{tabular}{|c|c|c|c|c|c|c|c|c|}
\hline \multirow[t]{3}{*}{ Health-related variable } & \multicolumn{4}{|c|}{ Married } & \multicolumn{4}{|c|}{ Unmarried $^{\mathrm{a}}$} \\
\hline & \multicolumn{2}{|c|}{ Age-adjusted } & \multicolumn{2}{|c|}{ Multivariate adjusted } & \multicolumn{2}{|c|}{ Age-adjusted } & \multicolumn{2}{|c|}{ Multivariate adjusted } \\
\hline & OR & $95 \% \mathrm{Cl}$ & OR & $95 \% \mathrm{Cl}$ & OR & $95 \% \mathrm{Cl}$ & OR & $95 \% \mathrm{Cl}$ \\
\hline \multicolumn{9}{|c|}{ Co-morbidities } \\
\hline \multicolumn{9}{|l|}{ Hypertension } \\
\hline No & \multicolumn{2}{|c|}{ Ref. } & & & \multicolumn{2}{|c|}{ Ref. } & & \\
\hline Yes & 1.22 & $0.82-1.81$ & 1.09 & $0.70-1.69$ & $1.67^{b}$ & $1.15-2.43$ & 1.36 & $0.88-2.10$ \\
\hline \multicolumn{9}{|l|}{ Vascular disorder } \\
\hline No & \multicolumn{2}{|c|}{ Ref. } & & & \multicolumn{2}{|c|}{ Ref. } & & \\
\hline Yes & 1.16 & $0.76-1.78$ & 0.96 & $0.59-1.55$ & $2.02^{b}$ & $1.37-2.98$ & $1.69^{\mathrm{b}}$ & $1.08-2.64$ \\
\hline \multicolumn{9}{|l|}{ Diabetes mellitus } \\
\hline No & Ref. & & & & Ref. & & & \\
\hline Yes & 1.48 & $0.96-2.30$ & 1.33 & $0.81-2.17$ & 1.12 & $0.72-1.72$ & 0.89 & $0.54-1.48$ \\
\hline \multicolumn{9}{|l|}{ Pulmonary disorder } \\
\hline No & \multicolumn{2}{|c|}{ Ref. } & & & \multicolumn{2}{|c|}{ Ref. } & & \\
\hline Yes & 1.84 & $0.93-3.63$ & 1.49 & $0.69-3.20$ & 1.83 & $0.94-3.57$ & 1.21 & $0.56-2.59$ \\
\hline \multicolumn{9}{|c|}{ Activities of daily living } \\
\hline ADL score & 1.10 & $0.96-1.26$ & 0.98 & $0.82-1.16$ & $1.16^{\mathrm{b}}$ & $1.02-1.32$ & 1.02 & $0.86-1.22$ \\
\hline \multicolumn{9}{|c|}{ Communication problems } \\
\hline \multicolumn{9}{|l|}{ Speech problems } \\
\hline No & \multicolumn{2}{|c|}{ Ref. } & & & \multicolumn{2}{|c|}{ Ref. } & & \\
\hline Yes & 1.45 & 0.68-3.09 & 1.02 & $0.41-2.57$ & $3.52^{\mathrm{b}}$ & $1.85-6.72$ & $4.19^{b}$ & $1.71-10.2$ \\
\hline \multicolumn{9}{|l|}{ Hearing problems } \\
\hline No & \multicolumn{2}{|c|}{ Ref. } & & & \multicolumn{2}{|c|}{ Ref. } & & \\
\hline Yes & $1.99^{\mathrm{b}}$ & $1.21-3.27$ & 1.31 & $0.62-2.78$ & $1.69^{b}$ & $1.09-2.64$ & 1.07 & $0.54-2.12$ \\
\hline \multicolumn{9}{|l|}{ Sight problems } \\
\hline No & \multicolumn{2}{|c|}{ Ref. } & & & \multicolumn{2}{|c|}{ Ref. } & & \\
\hline Yes & $1.80^{\mathrm{b}}$ & $1.12-2.89$ & 1.00 & $0.49-2.06$ & 1.41 & $0.92-2.16$ & 0.75 & $0.41-1.38$ \\
\hline
\end{tabular}

${ }^{a}$ Single, divorced, separated and widowed; ${ }^{b} P<0.05$.

Ref. = reference category; $\mathrm{OR}=$ odds ratio; $\mathrm{Cl}=$ confidence interval.

had no significant relationship with co-residence with married children. The latter result is similar to findings in Lebanon from data using a crude measure of disability among unmarried older Lebanese females [25]. Follow-up studies and in-depth interviews as well as an objective assessment of the health status of the older adult may assist in interpreting such results.

Overall, the results of the study showed an advantage for currently married older adults over their unmarried counterparts. The unmarried (mostly widowed and divorced) were more likely to host within their own households their married children, and this living arrangement did not indicate a positive outcome, whether in terms of economic assets or health indicators. The driving forces behind co-residence among married older people were mainly of socioeconomic origin, while among the unmarried, these included additionally health status of the older adult. Widowed older adults tend to be more dependent and have fewer choices when compared with their married counterparts $[8,9,20,21,26,27]$. Studies conducted in Egypt revealed that older adults may resume living with a child when they require financial assistance, when they are widowed, or when they need assistance in ADL due to declining health [8].

\section{Conclusion}

The aim of this study was to define the correlates of living with married children among older adults (aged $\geq$ 65 years) in Lebanon. The findings revealed that a combination of demographic, socioeconomic and healthrelated factors were correlated with co-residence. Marital status of the older adult appeared to affect co-residence with a married child; being widowed or divorced significantly increased the likelihood of co-residence. Among married older adults, co-residence with a married child was associated with lower socioeconomic status, whereas among 
the unmarried, availability of sons and additionally declining health were associated with co-residence with a married child. While solitary living among older people has been traditionally the focus of attention by policy-makers and service providers in Lebanon [28], the study findings showed that those living with a married child may also be a vulnerable group. Such information would help policy-makers in the country to design intervention measures towards achieving the Millennium Development Goals, especially in the area of poverty reduction and equal opportunities of development for older adults.

Competing interests: None declared

\section{References}

1. Sibai AM et al. Population ageing in Lebanon: current status, future prospects and implications for policy. Bulletin of the World Health Organization, 2004, 82:219-225.

2. Sibai A, Yamout R. Family-based old-age care in Arab countries: between tradition and modernity (63-76). In: Groth $\mathrm{H}$, Sousa-Poza A, eds. Population dynamics in Muslim countries: assembling the jigsaw. Heidelberg, Springer Berlin, 2012.

3. Chaudhuri A, Roy K. Gender differences in living arrangements among older persons in India. Journal of Asian and African Studies, 2007, 44(3):259-277.

4. Shah NM et al. Decline in co-residence of parents and children among older Kuwaiti men and women: what are the significant correlates? Journal of Cross-Cultural Gerontology, 2011, 26:157-174.

5. Department of Economic and Social Affairs, Population Division. Living arrangements of older persons around the world. New York, United Nations, 2005.

6. Department of Economic and Social Affairs, Population Division. World economic and social survey 2007: development in an ageing world. New York, United Nations, 2007.

7. Khadr Z. Living arrangements and social support systems of the older population in Egypt [doctoral thesis]. Ann Arbor, Michigan, University of Michigan, 1997.

8. Yount K. The patriarchal bargain and intergenerational coresidence in Egypt. Sociological Quarterly, 2005, 46:139-166.

9. Bongaarts J, Zimmer Z. Living arrangements of older adults in the developing world: an analysis of DHS household surveys. New York, Population Council, 2001 (Working Paper, No.148).

10. De Vos S, Holden K. Measures comparing living arrangements of the elderly: an assessment. Population and Development Review, 1998, 14:688-704.

11. Pal S. Effects of intergenerational transfers on elderly coresidence with adult children: evidence from rural India. Bonn, Germany, Institute for the Study of Labor, 2007 (Discussion Paper No. 2847).

12. VanWey L, Cebulko K. Intergenerational coresidence among small farmers in Brazilian Amazonia. Journal of Marriage and the Family, 2007, 69:1257-1270.

13. Yount K, Khadr Z. Gender, social change, and living arrangements among older Egyptians during the 1990s. Population Research and Policy Review, 2008, 27:201-225.

14. Sibai AM, Yount KM, Fletcher A. Marital status, intergenerational co-residence and cardiovascular and all-cause mortality among middle-aged and older men and women during wartime in Beirut: gains and liabilities. Social Science and Medicine, 2007, 64:64-76
15. Mehio-Sibai A, Beydoun MA, Tohme RA. Living arrangements of ever-married older Lebanese women: is living with married children advantageous? Journal of Cross-Cultural Gerontology, 2009, 24:5-17.

16. The Pan Arab Project for Family Health. Lebanon family health survey 2004: Principal report. Ministry of Social Affairs, Lebanon 2006 (http://www.pdslebanon.org/UserFiles/File/Lebanon\%20Report\%20English1.pdf, accessed 6 November 2013).

17. Katz $\mathrm{S}$ et al. Studies of illness in the aged. The index of ADL: A standardized measure of biological and psychosocial function. Journal of the American Medical Association, 1963, 185:914-919.

18. De Jong Gierveld J, Dykstra P, Schenk N. Living arrangements, intergenerational support types and older adult loneliness in Eastern and Western Europe. Demographic Research, 2012, 27:167-200.

19. Shah NM et al. Living arrangements of older women and men in Kuwait. Journal of Cross-Cultural Gerontology, 2002, 17:337-355.

20. Elman C, Uhlenberg P. Coresidence in the early twentieth century: Elderly women in the United States and their children. Population Studies, 1995, 49:501-517.

21. DaVanzo J, Chan A. Living arrangements of older Malaysians: who coresides with their adult children? Demography, 1994, 31:95-113.

22. Laithy H, Abu-Ismail K, Hamdan K. Poverty, growth and income distribution in Lebanon. Brasilia, Brazil, International Poverty Centre, 2008 (Country Study No.13).

23. Aykan H, Wolf D. Traditionality, modernity, and household composition: Parent-child coresidence in contemporary Turkey. Research on Aging, 2000, 22:395-421.

24. Autaç IA. Intergenerational living arrangements in Turkey. Journal of Cross-Cultural Gerontology, 1998, 13:241-264.

25. Obeid M. Living arrangements of Lebanese unmarried elderly women: evidence from the population and housing survey 1996. [Master's thesis]. Beirut, Lebanon American University of Beirut, 2004.

26. Grau MA. Residence patterns of aged widows in three Mediterranean communities and the organization of the care. History of the Family, 2002, 7:157-173.

27. Chen F. Residential patterns of parents and their married children in contemporary Chine: A life course approach. Population Research and Policy Review, 2005, 24:125-148.

28. Tohme $\mathrm{R}$ et al. Socioeconomic resources and living arrangements of older adults in Lebanon: who chooses to live alone? Ageing and Society, 2011, 31:1-17. 